\title{
PEMANFAATAN MINYAK DAUN CENGKEH (SYZYGIUM AROMATCUM L.) UNTUK PENGAWETAN IKAN
}

\author{
Winarsyih Muhidin dan Tahril \\ Jurusan Pendidikan MIPA \\ Fakultas Keguruan dan IImu Pendidikan Universitas Tadulako Palu
}

\begin{abstract}
Abstrak - This study aimed to examine the effect of clove leaf oil on the preservation of skipjack tuna fish. This research was conducted with variations in concentration and duration of storage. Analysis of the number of microbes was determined using the Pour method (pour plate), the organoleptic analysis used a test of the level of preference for color, aroma, texture, and taste. Analysis of protein levels used a UvVis spectrophotometer and analysis of fat content used the Soxletation method. The results showed that; (a) At a concentration of 5\% with a storage duration of 2 and 4 days, the $\mathrm{pH}$ was 6,60 and 6,65; at a concentration of $10 \%$ with a storage duration of 2 and 4 days, the $\mathrm{pH}$ was 7,0 and 7,03; at a concentration of $15 \%$ with a length of 2 and 4 days, the $\mathrm{pH}$ was 7,20 and 7,23. (b) At a concentration of $5 \%$ with a storage period of 2 and 4 days and dilutions of 10-3 and 10-4, the number of microbes obtained respectively were (151 CFU/mL and $263 \mathrm{CFU} / \mathrm{mL})$ and $(443 \mathrm{CFU} / \mathrm{mL}$ and $164 \mathrm{CFU} / \mathrm{mL}$ ); at a concentration of $10 \%$ with a storage duration of 2 and 4 days and dilution of 10-3 and 10-4, the number of microbes obtained respectively were (296 CFU/mL and $670 \mathrm{CFU} / \mathrm{mL}$ ) and (160 CFU/mL and 771 $\mathrm{CFU} / \mathrm{mL}$ ); at a concentration of $15 \%$ with a storage duration of 2 and 4 days and dilutions of 10-3 and 104 obtained that the number of microbes were (996 CFU/mL and $950 \mathrm{CFU} / \mathrm{mL}$ ) and $(917 \mathrm{CFU} / \mathrm{mL}$ and 742 $\mathrm{CFU} / \mathrm{mL}$ ). (c) The organoleptic test results showed that a concentration of $15 \%$ was the best concentration that can be used for fish preservation for 2 days and 4 days. (d) At $5 \%$ concentration with 2 and 4 days storage period, the protein content was obtained $8,153 \%$ and $4,988 \%$; at a concentration of $10 \%$ with a storage duration of 2 and 4 days obtained that protein levels were $8.679 \%$ and $5.131 \%$; at a concentration of $15 \%$ with a storage duration of 2 and 4 days obtained that protein levels were $9.869 \%$ and $8.983 \%$. (e) At a concentration of $5 \%$ with a storage duration of 2 and 4 days, the fat content obtained was $0.43 \%$ and $0.5888 \%$; at a concentration of $10 \%$ with a storage duration of 2 and 4 days the fat content obtained was $0.89 \%$ and 0.976 ; at a concentration of $15 \%$ with a storage duration of 2 and 4 days, the concentration of fat content was $0.963 \%$ and $1.029 \%$. Therefore, clove leaf oil is best used in preserving skipjack tuna meat.
\end{abstract}

Kata Kunci: Preservative, skipjack tuna meat, clove leaf oil (Syzygium aromaticum L.)

\section{PENDAHULUAN}

Tanaman cengkeh adalah tanaman rempah, dimana pada bagian utama tanaman cengkeh yang paling komersial yaitu bunga cengkeh yang sebagian besar digunakan pada industri rokok yang berkisar antara $80-90 \%$. Sedangkan pada bagian daun cengkeh belum termanfaatkan secara maksimal dan masih dianggap sebagai limbah yang kurang berguna (Aliah dkk., 2016).

Peningkatan produksi cengkeh dalam jangka pendek dapat dilakukan dengan cara memperbaiki struktur dari tanah dan juga kondisi tanaman (Santoso, 2018).

Kandungan senyawa pada cengkeh berbedabeda pada setiap bagiannya yaitu pada bunga,daun dan tangai bunga. Distribusi metabolit dalam bunga dan akar terutama dipengaruhi oleh variasi dari beberapa nutsiri tanah misalnya $\mathrm{Ca}$, $\mathrm{Mg}, \mathrm{P}, \mathrm{K}$ dan juga $\mathrm{Cu}$ (Taher dkk., 2018).

.Kandungan pada daun cengkeh (Syzygium aromaticum) yang dapat menimbulkan aroma khas pada daun cengkeh yaitu komponen minyak atsiri yang disebut sebagai eugenol. Berbagai hasil penelitian menunjukkan bahwa kandungan eugenol pada tanaman ini dapat digunakan sebagai fungisida dan bakterisida (Aliah dkk., 2016).

Ekstrak daun cengkeh mengandung senyawa yang dapat memicu imunitas yang spesifik dan juga non spesifik serta dapat mengaktifkan komponen seluler dari sistem imun, seperti fungsi fagositosis tanpa mempengaruhi imunitas humoral dan seluler (Wael dkk., 2018).

Minyak cengkeh merupakan salah satu bahan antibakteri alami yang melimpah dan dapat bermanfaat sebagai antibakteri (Andries dkk., 2014). Minyak atsiri cengkeh mengandung beberapa jenis komponen kimia yang menjadi komponen penyusun minyak. Komponen kimia penyusun minyak memberikan sifat yang khas yang akan menjadi ciri khas dari minyak atsiri (Pratiwi dkk., 2016).

Sub sektor perikanan merupakan sumber utama pengan dan gizi bagi masyarakat Indonesia. Produksi perikanan Indonesia lumayan besar dan juga semakin meningkat setap tahun, volume produksi perikanan pada tahun 2010 yaitu sebesar 10.826.502 ton (Wally dkk., 2015).

Produksi perikanan tangkap Indonesia pada tahun 2015 mencapai 6 juta ton. Komoditas utama yang memiliki kontribusi besar dalam industri perikanan tangkap Indonesia salah 
satunya adalah ikan cakalang, jumlah tangkap ikan cakalang mencapai 507 ribu ton (Aditia dkk., 2018).

Ikan cakalang adalah salah satu hasil perikanan tangkap yang dominan di Maluku, banyaknya hasil tangkapan ikan cakalang dapat mendorong masyrakat untuk mengolah ikan tersebut menjadi produk perikana yang ekonomis (Hadinoto dkk., 2016).

Ikan merupakan salah satu sumber protein yang sangat dibutuhkan oleh manusia, karena kandungan proteinnya tinggi, dan juga mengandung asam amino esensial yang di perlukan oleh tubuh, nilai biologisnya mencapai $90 \%$ dengan jaringan pengikat sedikit sehingga mudah untuk dicerna (Natsir, 2018).

Ikan dan hasil perikanan lainnya merupakan bahan pangan yang mudah membusuk, oleh karena itu proses pengolahan dan pengawetan yang dilakukan agar dapat menghambat atau menghentikan aktivitas zat-zat mikroorganisme perusak ataupun enzim-enzim yang dapat menyebabkan kemunduran mutu dan juga kerusakan pada ikan (Wally dkk., 2015).

Kemunduran mutu ikan disebabkan oleh aksi enzimatis dan juga bakteri, kedua aksi tersebut dapat mengurai komponen penyusun jaringan tubuh pada ikan, sehingga menghasilkan perubahan fisik seperti daging ikan dapat menjadi lunak dan juga perubahan kimia yang menghasilkan senyawa yang mudah menguap dan berbau busuk (Tumonda dkk., 2017).

Ikan memiliki komposisi kimia yang dapat bermanfaat bagi tubuh manusia, secara garis besar ikan mengandung air $(65-80 \%)$, protein $(17-22 \%)$, lemak $(0,5-2 \%)$ dan juga abu (1-2\%) (Ekasari dkk., 2017).

Tulisan ini dimaksudkan untuk mendeskripsikan tentang pemanfaatan minyak daun cengkeh (Syzygium aromatcum L.) untuk pengawetan ikan.

\section{METODOLOGI PENELITIAN}

Alat yang digunakan dalam penelitian ini yaitu, gelas kimia, gelas ukur, $\mathrm{pH}$ meter, Erlenmeyer, pipet tetes, spatula, batang pengaduk, aluminium foil, gunting, wadah sampel, neraca digital, pembakar bunsen, tabung reaksi, mikroflow (uv), cawan petri, autoklaf, vortex mixer, piknometer, rak tabung reaksi, soxlet,oven, dan desikator.

Bahan yang digunakan dalam penelitian ini yaitu minyak daun cengkeh hasil penyulingan, aquades, daging ikan cakalang, larutan $\mathrm{NaCl}$ fisiologis, $\mathrm{NaOH}$, etanol absolut.

\section{Pemurnian minyak daun cengkeh hasil penyulingan}

Merancang alat evaporator, lalu minyak dimasukkan kedalam labu alas bulat, kemudian memurnikan minyak daun cengkeh pada suhu $80^{\circ} \mathrm{C}$.

Penambahan minyak daun cengkeh
pada daging ikan cakalang

Daging ikan cakalang dicuci sampai

bersih, lalu daging ikan cakalang dimasukkan kedalam 7 wadah, lalu ditambahkan minyak daun cengkeh kedalam wadah 1 \& 2 dengan konsentrasi $5 \%$, wadah $3 \& 4$ dengan konsentrasi $10 \%$ dan wadah 5 \& 6 dengan konsentrasi $15 \%$. Kemudian ditutupi dengan menggunakan aluminium foil. Sedangkan wadah 7 tidak ditambahkan minyak daun cengkeh,lalu di diamkan 2 hari untuk wadah 1,3,5 dan 4 hari untuk wadah $2,4,6$. Sedangkan wadah 7 tidak didiamkan.

\section{Pengukuran ph daging ikan cakalang}

Pengukuran pada $\mathrm{pH}$ dapat dilakukan dengan cara yaitu mengambil daging ikan sebelum dan sesudah diawetkan, lalu menghaluskan daging ikan cakalang menggunakan lumpang dan alu. Kemudian, memasukkan daging ikan cakalang kedalam gelas kimia $50 \mathrm{~mL}$ dan menambahkan aquades sebanyak $10 \mathrm{~mL}$, dan dihomogenkan menggunakan batang pengaduk. Lalu mengukur $\mathrm{pH}$ ikan cakalang menggunakan $\mathrm{pH}$ meter.

\section{Pengamatan jumlah mikroba}

Metode yang digunakan adalah metode Tuang (pour plate). Langkah pertama yang dilakukan yaitu mensterilkan cawan petri, erlenmeyer, tabung reaksi, aquades, dan media NA menggunakan autoklaf. Lalu mengambil daging ikan cakalang yang sebelum dan sesudah diawetkan, ditimbang sebanyak 1 gram dan ditambahkan $9 \mathrm{~mL}$ aquades. Kemudian melakukan pengenceran bertingkat terhadap sampel dengan cara pengenceran $10^{-1}$ diperoleh dengan memasukkan $1 \mathrm{~mL}$ sampel ke dalam $9 \mathrm{~mL}$ larutan $\mathrm{NaCl}$ fisiologis, pengenceran $10^{-2}$ diperoleh dari memasukkan $1 \mathrm{~mL}$ sampel dari pengenceran $10^{-1}$ ke dalam $9 \mathrm{~mL}$ larutan $\mathrm{NaCl}$ fisiologis dan seterusnya sampai pengenceran $10^{-4}$. Setelah itu, pada seri pengenceran $10^{-3}$ dan $10^{-4}$ diambil $1 \mathrm{~mL}$, lalu di ambil $1 \mathrm{~mL}$ dari pengenceran $10^{-3}$ dan $10^{-4}$ lalu, dimasukkan ke dalam cawan petri steril, kemudian dituangkan ke dalam media NA ke dalam cawan steril, lalu di goyangkan agar merata (pour plate), kemudian diinkubasi pada suhu ruang selama 24 jam. Setelah 24 jam diinkubasi, lalu mengamati koloni yang tumbuh dengan menggunakan alat scan coloni 500.

\section{Uji organoleptik}

Uji organoleptic dilakukan dengan cara mengambil daging ikan yang sebelum dan sesudah diawetkan, lalu mengamati organoleptik (warna, bau, tekstur, dan rasa). Dimana penilaian tingkat kesukaan terhadap warna dilakukan dengan cara mengamati perubahan warna pada daging ikan, penilaian tingkat kesukaan terhadap bau dilakukan dengan cara mencium daging ikan, 
penilaian tingkat kesukaan terhadap tekstur dengan indra peraba, dan penilaian tingkat kesukaan terhadap rasa dengan indra perasa.

\section{Uji kadar protein}

Uji kandungan protein dapat dilakukan dengan metode spektrofotometri Uv-Vis. Pertama sampel ikan di ekstraksi dengan mengambil sampel ikan cakalang sebanyak 0,5 gram untuk masing-masing wadah, lalu dihaluskan dengan menggunakan lumpang dan alu sampai halus. Ditambahkan dengan $15 \mathrm{~mL} \mathrm{NaOH}$ dan di sheker selama 30 menit. Kemudian larutan disaring. Lalu, hasil ekstraksi diukur absorbansinya dengan spektrofotometer Uv-Visible pada panjang gelombang antara $280 \mathrm{~nm}$ dan $260 \mathrm{~nm}$.

\section{Uji kadar lemak}

Uji kadar lemak dapat dilakukan dengan metode soxhletasi. Sampel ikan ditimbang sebanyak 10 gram dan dimasukkan ke dalam selongsong kertas. Lalu disumbat selongsong kertas yang berisi sampel dengan kapas. Kemudian dikeringkan pada oven pada suhu $80^{\circ} \mathrm{C}$ selama kurang lebih 1 jam, lalu masukkan ke dalam soxlet yang dihubungkan dengan labu lemak yang telah dikeringkan dan diketahui bobotnya. (timbang labu sebelum dipakai). Lalu, diuapkan pelarutnya secara vakum dengan menggunakan rotary vakum evaporator. Setelah itu, dikeringkan ekstrak lemak dalam oven pengering suhu $105^{\circ} \mathrm{C}$ selama 1 jam. Kemudian di dinginkan dalam desikator dan di timbang hingga bobot tetap.

\section{HASIL DAN PEMBAHASAN}

\section{Pengukuran pH pada daging ikan cakalang}

$\mathrm{pH}$ adalah derajat kesamaan yang digunakan untuk menyatakan tingkat keasaman atau kebasahan yang dimliki oleh suatu larutan..

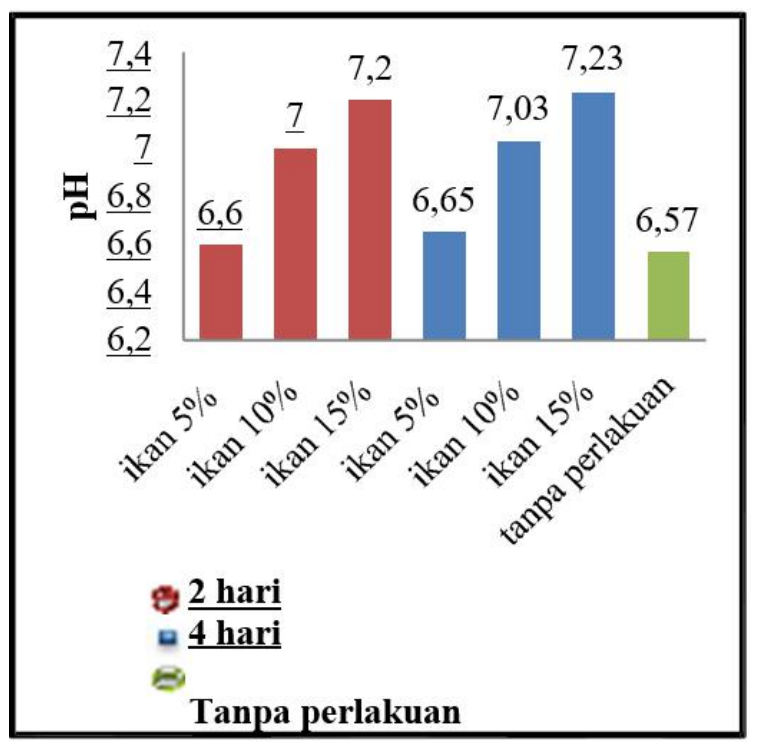

Gambar 1. Grafik pH terhadap lama pendiaman dan perbedaan konsentrasi.

Berdasarkan gambar 1, menunjukkan bahwa $\mathrm{pH}$ daging ikan cakalang berkisaran antara 6,57-7,23. Untuk pH terendah yaitu 6,57 pada sampel tanpa pendiaman, sedangkan untuk $\mathrm{pH}$ tertinggi 7,23 pada sampel yang berkonsentrasi $15 \%$ pada pendiaman 4 hari. Dimana, dapat disimpulkan bahwa semakin tinggi konsentrasi pada minyak daun cengkeh, maka semakin tinggi $\mathrm{pH}$ yang didapatkan pada setiap pendiaman. Nilai $\mathrm{pH}$ merupakan salah satu indikator atau parameter yang digunakan untuk menentukan tingkat kesegaran pada ikan. Ikan busuk memiliki $\mathrm{pH}$ sekitar 10-11 (kondisi basa). pH ikan akan menurun jika ada glikogen yang terurai menjadi asam laktat akan meningkatkan keasaman pada daging ikan dan seteleh kandungan glikogen habis maka $\mathrm{pH}$ akan meningkat terus. Faktor yang dapat mempengaruhi tinggi rendahnya $\mathrm{pH}$ yaitu nutrisi pada ikan dan juga besarnya tekanan (stress) dan gerakan (exercise) yang dialami ikan sebelum mati akan berpengaruh besar terhadap cadangan glikogen dan pada akhirnya terhadap nilai $\mathrm{pH}$ akhir pada daging. Suhu rendah juga dapat menghambat laju penurunan pada $\mathrm{pH}$,dan begitupun dengan sebaliknya suhu tinggi dapat mempercepat laju penurunan pada $\mathrm{pH}$ tersebut (Fikri dkk., 2017).

\section{Pengukuran jumlah mikroba}

Aktivitas anti bakteri pada minyak atsiri tergantung pada suatu komponen dan juga persentase senyawa penyusunnya (Paliling dkk., 2016). 


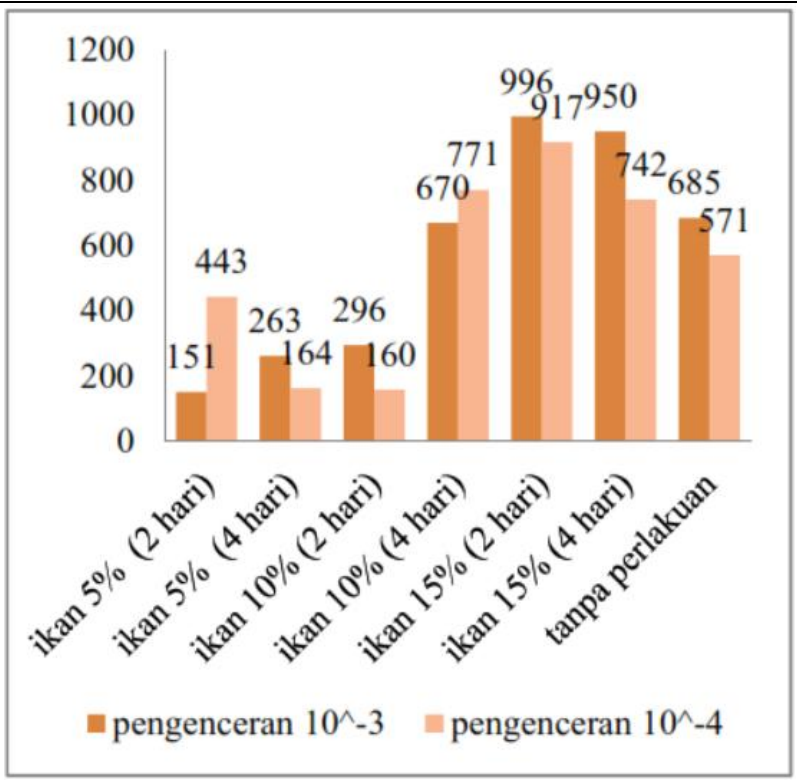

Gambar 2. Grafik mikroba terhadap lama pendiaman dan perbedaan konsentrasi.

Berdasarkan gambar 2, menunjukkan bahwa hasil pengamatan pengaruh perlakuan penambahan minyak daun cengkeh pada berbagai konsentrasi dan lama waktu pendiaman menunjukkan perbedaan total bakteri pada daging ikan cakalang. Berdasarkan hasil penelitian, menunjukkan bahwa rerata jumlah mikroba yaitu $151 \times 10-3-996 \times 10-3$. Jumlah mikroba yang terendah berada pada sampel yang berkonsentrasi $5 \%$ dengan pendiaman 2 hari, dan jumlah mikroba yang tertinggi berada pada sampel yang berkonsentrasi $15 \%$ dengan pendiaman 2 hari. Hal ini di duga karena penyerapan minyak daun cengkeh sebagai anti mikroba belum menyerap secara menyeluruh ke dalam daging ikan cakalang, sehingga jumlah mikroba relatif naik turun pada konsentrasi yang berbeda. Jumlah mikroba masih termasuk baik untuk tubuh karena kurang dari pada SNI, jumlah mikroba pada SNI yaitu $5 \times 105 \mathrm{CFU} / \mathrm{g}$. Dapat dilihat bahwa total bakteri pada daging ikan cakalang cenderung meningkat dengan lamanya waktu pendiaman tetapi rendahnya konsentrasi minyak daun cengkeh yang di tambahkan belum terlalu mempengaruhi total bakteri. Hal ini di duga di sebabkan oleh penyerapan minyak daun cengkeh belum sempurna, sehingga peresapan hanya terjadi pada permukaan ikan saja sehingga tidak dapat menghambat pertumbuhan bakteri karena faktor-faktor yang mendukung pertumbuhan bakteri seperti pH dan suhu (Andayani dkk.,2014).

Sifat antibakteri dan juga sifat anti oksidan pada bahan alam umumnya selalu terkait dengan jumlah besarnya kandungan fenol yang dapat menyebabkan rusaknya membran sitoplasma pada bakteri (Dinda dkk., 2017).

\section{Pengamatan uji organoleptik}

1. Warna

Warna adalah atribut mutu yang merupakan faktor penting dalam proses penilaian suatu produk karena merupakan indikasi perubahan kimia dalam makanan (Ginayati dkk., 2015).

Tabel 1 Karakteristik warna terhadap lama pendiaman dan perbedaan konsentrasi

\begin{tabular}{cccccc}
\hline \multirow{2}{*}{ Sampel } & \multirow{2}{*}{$\begin{array}{c}\text { Konsentras } \\
\text { i (\%) }\end{array}$} & $\begin{array}{c}\text { Waktu } \\
\text { (hari) }\end{array}$ & $\begin{array}{c}\text { Sangat } \\
\text { suka }\end{array}$ & suka & $\begin{array}{c}\text { tidak } \\
\text { suka }\end{array}$ \\
\hline 1 & 5 & 2 & 5 & 8 & 2 \\
\hline 2 & 5 & 4 & 3 & 5 & 7 \\
\hline 3 & 10 & 2 & 4 & 6 & 5 \\
\hline 4 & 10 & 4 & 2 & 5 & 8 \\
\hline 5 & 15 & 2 & 5 & 7 & 3 \\
\hline 6 & 15 & 4 & 1 & 3 & 11 \\
\hline 7 & - & - & 10 & 5 & 0 \\
\hline
\end{tabular}

Berdasarkan tabel 1, menunjukkan bahwa lama pendiaman dan konsentrasi minyak daun cengkeh sangat berpengaruh pada proses pengawetan daging ikan cakalang, dapat dilihat pada tingkat kesukaan panelis yang tertinggi yaitu pada perlakuan tanpa pendiaman, lalu pada perlakuan pendiaman 2 hari, dan pada perlakuan pendiaman 4 hari. Kualitas daging segar dapat dilihat dari warna daging sendiri. Zat warna yang terdapat pada daging disebut mioglobin adalah 
senyawa protein terkonjugasi yang berwarna merah ungu. Warna merah ungu ini akan segera berubah menjadi merah cerah bila mioglobin kontak dengan oksigen dari udara dan membentuk oksimioglobin. Tingkat kecerahan warna pada daging ikan, ditentukan oleh tipisnya lapisan oksimioglobin pada permukaan daging. Jika daging segar disimpan dalam wadah yang tidak tembus oksigen, maka oksigen yang terdapat di dalam wadah akan habis dikarenakan oleh adanya aktivitas biokimia dan mikroorganisme pada permukaan daging ikan. Sehingga lama kelamaan warna pada daging ikan akan berubah warna sampai berwarna kuning atau tidak berwarna (daging ikan rusak). Jadi, semakin tinggi konsentrasi pada minyak daun cengkeh, maka semakin lambat proses perubahan warna pada daging ikan cakalang dikarenakan minyak daun cengkeh dapat menghambat pada proses pertumbuhan bakteri pada daging ikan.

\section{Aroma}

Aroma amoniak adalah salah satu hasil penguraian protein dari adanya aktivitas pada bakteri, sehingga hubungan pada jumlah bakteri dengan amoniak yang terbentuk akan berbanding lurus (Regista dkk., 2017)..

Tabel 2 . Karakteristik aroma terhadap waktu lama pendiaman dan perbedaan konsentrasi.

\begin{tabular}{|c|c|c|c|c|c|}
\hline \multirow[b]{2}{*}{ Sampel } & \multirow[b]{2}{*}{$\begin{array}{c}\text { Konsentras } \\
\text { i (\%) }\end{array}$} & \multirow[b]{2}{*}{$\begin{array}{l}\text { Waktu } \\
\text { (hari) }\end{array}$} & \multicolumn{3}{|c|}{ Karakteristik aroma } \\
\hline & & & $\begin{array}{c}\text { sangat } \\
\text { suka }\end{array}$ & suka & $\begin{array}{l}\text { tidak } \\
\text { suka }\end{array}$ \\
\hline 1 & 5 & 2 & 1 & 9 & 5 \\
\hline 2 & 5 & 4 & 1 & 6 & 8 \\
\hline 3 & 10 & 2 & 0 & 7 & 8 \\
\hline 4 & 10 & 4 & 0 & 6 & 9 \\
\hline 5 & 15 & 2 & 0 & 7 & 8 \\
\hline 6 & 15 & 4 & 0 & 4 & 11 \\
\hline 7 & - & - & 4 & 7 & 4 \\
\hline
\end{tabular}

Berdasarkan hasil penelitian tabel 2, menunjukkan bahwa daging ikan cakalang yang memiliki konsentrasi rendah telah mengalami penurunan nilai baik untuk pendiaman 2 hari dan 4 hari. Penurunan nilai aroma diakibatkan oleh timbulnya aroma yang kuat, tercium aroma amoniak dan tengik pada daging ikan cakalang, sehingga dapat menyebabkan daging ikan cakalang dari segi aroma sudah tidak disukai oleh panelis. Kehadiran mikroorganisme pada ikan juga mengakibatkan perubahan aroma.
Jadi, semakin tinggi konsentrasi minyak daun cengkeh, maka semakin lambat proses perubahan bau pada daging ikan dikarenakan minyak daun cengkeh bisa menghambat proses pertumbuhan bakteri pada daging ikan.

\section{Tekstur}

Penilaian tekstur dapat ditentukan oleh kandungan protein dan lemak daging ikan (Wulandari, 2016).

Tabel 3 Karakteristik tekstur dengan waktu lama pendiaman dan perbedaan konsentrasi.

\begin{tabular}{|c|c|c|c|c|c|}
\hline \multirow[b]{2}{*}{ Sampel } & \multirow[b]{2}{*}{$\begin{array}{c}\text { Konsentras } \\
\text { i ( } \%)\end{array}$} & \multirow[b]{2}{*}{$\begin{array}{l}\text { Waktu } \\
\text { (hari) }\end{array}$} & \multicolumn{3}{|c|}{ Karakteristik tekstur } \\
\hline & & & $\begin{array}{l}\text { sangat } \\
\text { suka }\end{array}$ & suka & $\begin{array}{l}\text { tidak } \\
\text { suka }\end{array}$ \\
\hline 1 & 5 & 2 & 5 & 9 & 1 \\
\hline 2 & 5 & 4 & 1 & 4 & 10 \\
\hline 3 & 10 & 2 & 4 & 8 & 3 \\
\hline 4 & 10 & 4 & 0 & 4 & 11 \\
\hline 5 & 15 & 2 & 2 & 8 & 5 \\
\hline 6 & 15 & 4 & 0 & 3 & 12 \\
\hline 7 & - & - & 4 & 9 & 2 \\
\hline
\end{tabular}

Berdasarkan tabel 3. dapat dilihat nilai ratarata kesukaan uji organoleptik tekstur yang paling tinggi pada perlakuan tanpa pendiaman, sedangkan yang paling rendah yaitu pada waktu pendiaman 4 hari. Semakin rendah konsentrasi dan semakin lama penyimpanan akan mengalami penurunan nilai organoleptiknya dari segi tekstur. Pertumbuhan jamur pada bagian permukaan daging ikan. Bakteri maupun enzim dapat mengakibatkan degradasi jaringan pengikat yang menyebabkan penurunan nilai tekstur sehingga menjadi lunak.

4. Rasa 
Rasa dapat disebabkan oleh faktor lingkungan yang mendukung pertumbuhan mikroba selama penyimpanan misalnya suhu, $\mathrm{O} 2$.

Tabel 4. Karakteristik rasa terhadap waktu lama pendiaman dan perbedaan konsentrasi.

\begin{tabular}{cccccc}
\hline \multirow{2}{*}{ Sampel } & \multirow{2}{*}{$\begin{array}{c}\text { Konsentras } \\
\text { i (\%) }\end{array}$} & $\begin{array}{c}\text { Waktu } \\
\text { (hari) }\end{array}$ & $\begin{array}{c}\text { sangat } \\
\text { suka }\end{array}$ & suka & $\begin{array}{c}\text { tidak } \\
\text { suka }\end{array}$ \\
\hline 1 & 5 & 2 & 4 & 6 & 5 \\
\hline 2 & 5 & 4 & 2 & 4 & 9 \\
\hline 3 & 10 & 2 & 2 & 5 & 8 \\
\hline 4 & 10 & 4 & 0 & 5 & 10 \\
\hline 5 & 15 & 2 & 0 & 6 & 9 \\
\hline 6 & 15 & 4 & 0 & 4 & 11 \\
\hline 7 & - & - & 7 & 8 & 0 \\
\hline
\end{tabular}

Berdasarkan hasil penelitian, tabel 4, menunjukkan bahwa ikan yang telah mengalami penyimpanan dan memiliki konsentrasi yang rendah mengalami penurunan organoleptiknya dari segi rasa. Ikan yang mengalami pendiaman 4 hari dari segi rasa sangat rendah. Hal ini disebabkan oleh daging ikan sudah ditumbuhi oleh bakteri dan jamur sehingga tingkat kesukaan panelis terhadap cita rasa menurun. Minyak daun cengkeh akan menghasilkan berbagai pengaruh terdahap bahan pangan terutama dapat menghambat pertumbuhan mikroba pembusuk yang mengkontaminasi. Rasa yang tidak enak disebabkan oleh faktor lingkungan yang mendukung pertumbuhan mikroba selama penyimpanan misalnya suhu, $\mathrm{O}_{2}$, sehingga tumbuhnya mikroba akan merusak daging dan tingkat konsumen menurun.

\section{Uji kadar Protein}

Protein dapat digunakan dalam indicator kualitas pakan, pakan diperlukan untuk proses pertumbuhan, kesehatan ikan, dan juga peningkatan mutu produksi (Tahapari \& Darmawan, 2018). Protein tersebut juga sangat penting bagi kehidupan manusia selain karbohidrat dan juga lemak, dimana yang berfungsi sebagai zat pembangun dan juga zat pengatur (La'lang dkk., 2018). Protein pada ikan menyediakan lebih kurang 2/3 dari kebutuhan protein hewani yang diperlukan manusia. Protein tersebut memegang peranan penting dalam struktur dan fungsi tubuh, seperti pada tumbuhan dan juga reproduksi. Ikan tidak mampu mensintesis protein, asam amino dari senyawa nitrogen anorganik (Ramlah dkk., 2016).

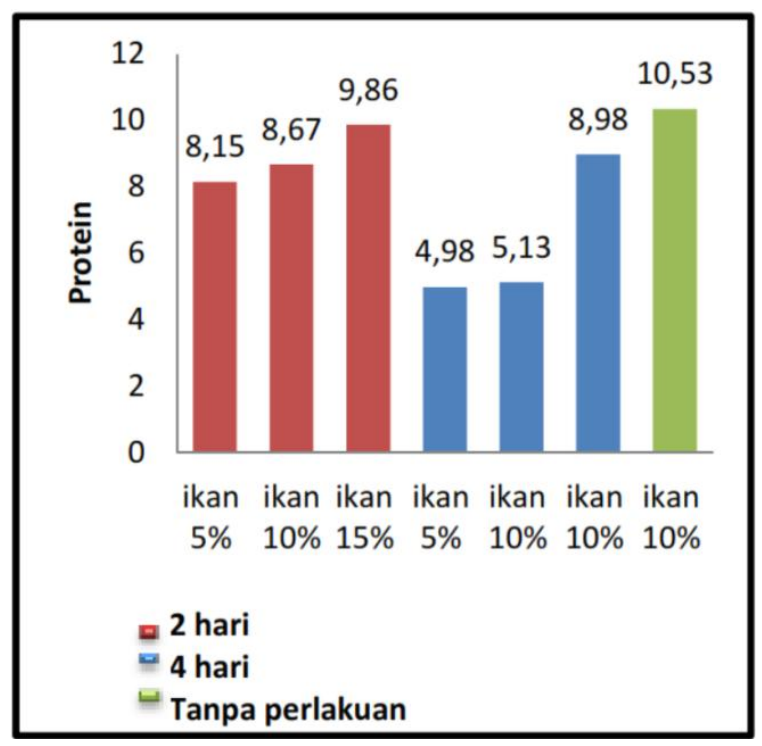

Gambar 3. Grafik protein terhadap waktu lama pendiaman dan perbedaan konsentrasi 


\begin{abstract}
Berdasarkan gambar 3, menunjukkan bahwa jumlah kadar protein berkisar antara 4,988- 10,354. Kadar protein yang terendah terdapat pada daging ikan yang berkonsentrasi $5 \%$ dengan pendiaman 4 hari dan kadar protein tertinggi terdapat pada sampel tanpa pendiaman. Dapat di lihat pada grafik di atas menunjukkan bahwa, berdasarkan pada waktu lama pendiaman kadar proteinnya semakin menurun. Pada umumnya protein di dalam bahan pangan menentukan mutu bahan pangan itu sendiri. Hal ini di akibatkan oleh kemampuan mikroorganisme yang dapat menghasilkan enzim proteolitik yang dapat memecah molekul protein $40-50 \%$ dalam bahan pangan (Wisuthiphaet dkk., 2015). Selain itu, penurunan kadar protein juga di pengaruhi oleh total koloni bakteri karena salah satu faktor yang di butuhkan oleh bakteri untuk pertumbuhannya
\end{abstract}

adalah protein. Pertumbuhan pada suatu bakteri dapat mempercepat proses denaturasi protein, sehingga kadar protein akan menurun. Untuk proses penghambatan suatu protein dapat diketahui dengan pengukuran serapan secara spektrofotometri Uv-Visible (Farida dkk., 2018).

\title{
Uji kadar lemak
}

Kandungan lemak pada ikan berkisar antara $1-20 \%$, lemak ikan tersebut sebagian besar adalah asam lemak tak jenuh yang dibutuhkan untuk pertumbuhan dan juga dapat butuhkan untuk menurunkan kolesterol darah. Ikan mengandung jumlah lemak yang bervariasi,dimana ada yang memiliki jumlah lemak yang tinggi dan ada juga yang memiliki kandungan lemak yang rendah

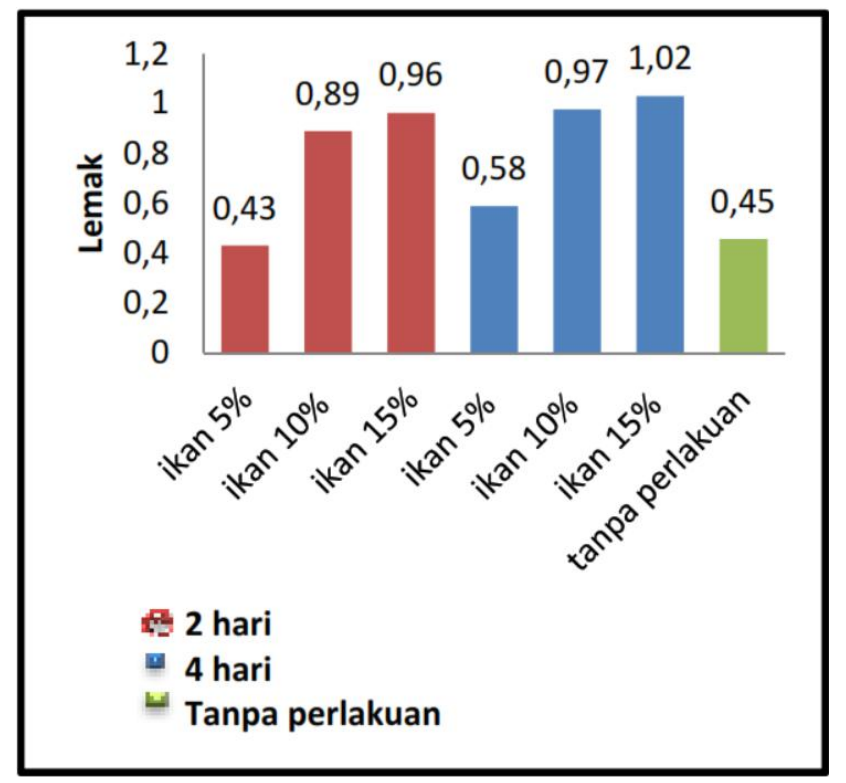

Gambar 4. Grafik lemak terhadap waktu lama pendiaman dan perbedaan konsentrasi.

Berdasarkan gambar 4, menunjukkan jumlah rerata lemak 0,430 - 1,029. Jumlah lemak terendah berada pada sampel yang berkonsentrasi $5 \%$ dengan pendiaman 2 hari dan jumlah lemak tertinggi berada pada sampel yang berkonsentrasi $15 \%$ dengan pendiaman 4 hari. Dari grafik diatas dapat dilihat bahwa semakin tinggi konsentrasi minyak daun cengkeh dan lama waktu pendiaman, kadar lemak pada sampel akan semakin bertambah. Hal ini di karenakan minyak daun cengkeh terabsorb ke dalam daging ikan cakalang, sehingga kadar lemak pada daging ikan cakalang semakin tinggi seiring dengan bertambahnya konsentrasi pada minyak daun cengkeh dan lama waktu pendiaman pada sampel daging ikan cakalang. Kandungan lemak pada daging ikan cakalang dapat di pengaruhi oleh komposisi jumlah minyak daun cengkeh, semakin banyak digunakan minyak daun cengkeh pada daging ikan cakalang, maka lemak pada daging ikan akan semakin tinggi (Koir dkk., 2017). Daging memiliki tempat penyimpanan lemak intramaskular akan mencair dan dapat berdifusi masuk kedalam matriks dari serabut otot pada daging, sehingga dapat meningkatkan kandungan lemak pada daging (Erfiza dkk., 2018).

\section{KESIMPULAN}

Berdasarkan hasil penelitian yang diperoleh dapat disimpulkan bahwa, minyak daun cengkeh efektif terhadap pengawetan ikan baik dari segi $\mathrm{pH}$, jumlah mikroba, uji organoleptik, uji protein dan uji kadar lemak. Semakin tinggi konsentrasi mniyak daun cengkeh, maka semakin besar kemampuan terhadap pengawetan daging ikan cakalang, terbukti bahwa pada konsentrasi $15 \%$ lebih baik dibanding pada konsentrasi $10 \%$ dan juga 
konsentrasi $5 \%$, baik pada proses pendiaman selama 2 hari dan juga pendiaman selama 4 hari.

\section{UCAPAN TERIMA KASIH}

Penulis mengucapkan terima kasih kepada bapak Tahril yang telah memberikan banyak masukan dan juga saran untuk tulisan ini. Dan juga kepada pihak yang telah membantu penelitian ini, khususnya kepala Laboratorium penelitian kimia Fakultas MIPA dan Laboratorium Agroteknologi universitas tadulako, sehingga penelitian ini berjalan dengan lancar.

\section{DAFTAR PUSTAKA}

[1] Aditia, R. P., Desniar, D., \& Trilaksani, W. (2018). Aktivitas antioksidan dan antibakteri hidrolisat protein hasil fermentasi telur ikan cakalang. Jurnal Pengolahan Hasil Perikanan Indonesia, 21(1),1. [2] D.

Yurahly, "Perbedaan Hasil Belajar Fisika Model Pembelajaran Guided Discovery dan Direct Instruction Berbasis Keterampilan Proses Sains pada Siswa Kelas X SMP Negeri 4 Palu", Skripsi, Pendidikan Fisika, Universitas Tadulako, Palu, 2014.

[2] Aliah, N., Susilawaty, A., \& Ibrahim, I. A. (2016). Uji efektivitas ekstrak daun cengkeh (Syzigium aromaticum L.) sebagai repellent semprot terhadap lalat rumah (Musca domestica). Jurnal Kesehatan Lingkungan, 2(3), 113-120.

[3] Andayani, T., Hendrawan, Y., \& Yulianingsih, R. (2014). Minyak atsiri daun sirih merah (Piper crocatum) sebagai pengawet alami Pada ikan teri (Stolephorus indicus). Jurnal Bioproses Komoditas Tropis, 2(2), 123-130.

[4] Andries, J. R., Gunawan, P. N., \& Supit, A. (2014). Uji efek anti bakteri ekstrak bunga cengkeh terhadap bakteri Streptococcus mutans secara in vitro. E-Gigi, 2(2).

[5] Ekasari, D., Suwetja, I. K., \& Montolalu, L. A. (2017). Uji mutu ikan cakalang (Katsuwonus pelamis-L) dan ikan tongkol (Euthynnus affinis) segar di tpi tumumpa selama penyimpanan dingin. Media Teknologi Hasil Perikanan, 5(2), 40.

[6] Erfiza, N. M., Hasni, D., \& Syahrina, U. (2018). Evaluasi nilai gizi masakan daging khas Aceh (Sie Reuboh) berdasarkan variasi penambahan lemak sapi dan cuka aren. Jurnal Teknologi dan Industri Pertanian Indonesia, 10(1), 28-35.

[7] Farida, Y., Rahmat, D., \& Amanda, A. W. (2018).nUji aktivitas antiinflamasi nanopartikel ekstrak etanol rimpang temulawak (Curcuma xanthorrhiza Roxb.) dengan metode penghambatan denaturasi protein. Jurnal Ilmu Kefarmasian Indonesia, 16(2), 225-230.
[8] Andries, J. R., Gunawan, P. N., \& Supit, A. (2014). Uji efek anti bakteri ekstrak bunga cengkeh terhadap bakteri Streptococcus mutans secara in vitro. E-Gigi, 2(2).

[9] Hadinoto, S., Kolanus, J. P. M., \& Manduapessy, K. R. W. (2016). The characteristic of quality skipjack tuna (Katsuwonus pelamis) liquid smoke using liquid smoke from coconut shell. Majalah Biam Kementerian Perindustrian, 12(1), 20-26.

[10] Koir, R. I., Devi, M., \& Wahyuni, W. (2017). Analisis proksimat dan uji organoleptik getuk lindri substitusi umbi gembili (Dioscorea Esculenta L). Teknologi dan Kejuruan: Jurnal Teknologi, Kejuruan, dan Pengajarannya, 40(1), 87-98.

[11] La'lang, M., Darmawati, S., \& Kartika, A. I. (2018). Analisis profil protein daging kerbau dengan variasi konsentrasi garam serta pengasapan berbasis SDS-PAGE. Prosiding Seminar Nasional Mahasiswa Unimus, 1(2011), 66-72.

[12] Lisa Ginayati, M. Faisal, \& Suhendrayatna. (2015). Pemanfaatan asap cair dari pirolisis cangkang kelapa sawit sebagai pengawet alami tahu. Jurnal Teknik Kimia USU, 4(3), 711.

[13] Natsir, N. A. (2018). Analisis kandungan protein total ikan kakap merah dan ikan kerapu bebek. Biosel: Biology Science and Education, 7(1), 49.

[14] Oktarina Dinda, Sumpono, \& Rina Elvia. (2017). Uji efektifitas asap cair cangkang buah hevea braziliensis terhadap aktivitas bakteri Escherichia coli. Alotrop, 1(1), 1-5.

[15] Paliling, A., Posangi, J., \& Anindita, P. S. (2016). Uji daya hambat ekstrak bunga cengkeh (Syzygium aromaticum) terhadap bakteri Porphyromonas gingivalis. E-Gigi, 4(2).

[16] Pratiwi, L., Rachman, M. S., \& Hidayati, N. (2016). Ektraksi minyak atsiri dari bunga cengkeh dengan pelarut etanol dan nheksana. University Research Colloquium, 655-661.

[17] Ramlah, Soekendarsi, E., Hasyim, Z., \& Hasan, S. (2016). Perbandingan kandungan gizi ikan nila Oreochromis niloticus asal danau mawang kabupaten Gowa dan danau universitas Hasanuddin kota Makassar. Jurnal Biologi Makasar. (Bioma), 1(1), 39-46.

[18] Regista, R., Ambeng, A., Litaay, M., \& Umar, M. R. (2017). Pengaru pemberian vermikompos cair lumbricus rubellus hoffmeister pada pertumbuhan Chlorella sp. Bioma : Jurnal Biologi Makassar, 2(1), 1-8.

[19] Santoso, A. B. (2018). Upaya mempertahankan eksistensi cengkeh di provinsi Maluku melalui rehabilitasi dan peningkatan produktivitas. Jurnal Penelitian dan Pengembangan Pertanian, 37(1), 26.

[12] Tahapari, E., \& Darmawan, J. (2018). Kebutuhan protein pakan untuk performa 
optimal benih ikan patin pasupati (pangasiid). Jurnal Riset Akuakultur, 13(1), 47.

[20] Taher, D. M., Solihin, D. D., Cahyaningsih, U., \& Sugita, P. (2018). Ekstrak metanol cengkeh (Syzygium Aromaticum L.) Merry \& Perry) varietas tuni buru selatan sebagai Antimalaria. Acta Veterinaria Indonesian, 6(2), 38-47.

[21] Tumonda, S., Mewengkang, H. W., \& Timbowo, S. M. (2017). Kajian mutu ikan cakalang (Katsuwonus pelamis L) asap terhadap nilai kadar air dan $\mathrm{pH}$ selama penyimpanan. Media Teknologi Hasil Perikanan, 5(2), 64.

[22] Wael, S., Mahulette, F., Wilhelmus Watuguly, T., \& Wahyudi, D. (2018). Pengaruh ekstrak daun cengkeh
(Syzygium aromaticum L.) terhadap limfosit dan makrofag mencit balb/c. Jalan Yos Sudarso No. 338 Serengan, 23(2), 79-83.

[23] Wally, E., Mentang, F., \& Montolalu, R. I. (2015). Kajian mutu kimiawi ikan cakalang (Katsuwonus pelamis L.) asap (fufu) selama penyimpanan suhu ruang dan suhu dingin. Media Teknologi Hasil Perikanan, 4(2), 7- 12.

[24] Wisuthiphaet, N., Kongruang, S., \& Chamcheun, C. (2015). Production of fish protein hydrolysates by acid and enzymatic hydrolysis. Journal of Medical and Bioengineering, 4(6), 466-470.

[25] Wulandari, F. (2016). Analisis kandungan gizi, nilai energi, dan uji organoleptik cookies tepung beras dengan substitusi tepung sukun. Jurnal Aplikasi Teknologi Pangan, 5(3), 107-112. 